\title{
DEPOSITION AND NUTRITIONAL QUALITY OF THE LITTER OF PURE STANDS OF Eucalyptus camaldulensis AND Acacia mangium
}

\author{
APORTE E QUALIDADE NUTRICIONAL DA SERAPILHEIRA DE PLANTIOS \\ PUROS DE Eucalyptus camaldulensis $E$ Acacia mangium
}

\section{Cristiane Figueira da SILVA ${ }^{1}$; Élida Ribeiro do CARMO ${ }^{2}$; Marco Antônio MARTINS ${ }^{3}$; Marta Simone Mendonça de FREITAS ${ }^{4}$; Marcos Gervasio PEREIRA ${ }^{5}$; Eliane Maria Ribeiro da SILVA ${ }^{6}$}

1. Pós-Doutoranda do curso de Pós- Graduação em Ciências Ambientais e Florestais, Universidade Federal Rural do Rio de Janeiro - UFRRJ, Seropédica, RJ, Brasil. Bolsista da CAPES. cfigueirasilva@yahoo.com.br; 2. Mestre em produção vegetal, Universidade Estadual do Norte Fluminense Darcy Ribeiro - UENF, Campos dos Goytacazes, RJ, Brasil; 3. Professor Titular da UENF, Campos dos Goytacazes, RJ, Brasil; 4. Professora Associada da UENF, Campos dos Goytacazes, RJ, Brasil; 5. Professor Adjunto do Departamento de Solos, UFRRJ, Seropédica, RJ, Brasil; 6. Pesquisadora da Embrapa Agrobiologia, Seropédica, RJ, Brasil.

\begin{abstract}
The aim of this study was to evaluate the contribution of pure stands of Eucalyptus camaldulensis and Acacia mangium for litter deposition and nutrient return in a pit of clay extraction in northern Rio de Janeiro (RJ). We conducted a randomized block design experiment with two treatments and three replications. For the evaluation of the annual deposition of litter and nutrients (N, P, K, Ca and Mg), we used circular collectors during a year (from July 2006 to June 2007). The planting of Acacia mangium in clay extraction pits contributed with the largest annual deposition of litter and with a litter of better quality compared to Eucalyptus camaldulensis, with higher levels of $\mathrm{P}$ and $\mathrm{N}$ and lower C:N and polyphenol:N ratios. This fact possibly allows higher rates of decomposition by edaphic microorganisms and, hence, a faster release of these nutrients to the soil. In addition, the planting of legumes showed higher annual deposition of $\mathrm{P}$ and $\mathrm{N}$
\end{abstract}

KEYWORDS: Nutrient cycling. Degraded area. Arboreal Legume.

\section{INTRODUCTION}

The exploitation of mineral resources is among the human activities that most promote impacts on natural areas (SILVA; MARGUERON, 2002; CABRAL; ALBUQUERQUE, 2012), due to the drastic landscape alteration and removal of vegetation and soil (VALICHESKI; MARCIANO, 2008; MECHI; SANCHES, 2010). In northern Rio de Janeiro (RJ) some areas have been exploited by the activity of extracting clay for brick and tile production, which has led to the degradation of the soil and landscape (COSTA JUNIOR, 1997; RODRIGUES et al., 2006; VALICHESKI; MARCIANO, 2008).

The revegetation of these areas with arboreal Fabaceae species that fix atmospheric nitrogen and eucalyptus have been a viable option for the rehabilitation of the soil, promoting improvements in its chemical and biological qualities (SCHIAVO et al., 2009; MENDONÇA, 2006; BATISTA et al., 2008; SILVA et al., 2013, 2012). This fact possibly due, among other factors, to the litter deposited to the soil by plant species, since it constitutes the major route of transferring organic matter, nitrogen, phosphorus and calcium to the soil (SELLE, 2007). In addition, the litter provides a variety of features and micro-habitats for soil biota (ALBUQUERQUE et al., 2009), and an effective protection against soil erosion, depending on the layer formed on the soil, avoiding the direct impact of rain water (CORRÊA NETO et al., 2001; OCHIAI; NAKAMURA, 2004). Thus, the dynamics of litter and its nutrients, represented by the input via deposition and output via decomposition and/or mineralization, is important for maintaining both native forests and forest plantations (FERREIRA et al., 2007).

Although essential to the sustainability of degraded areas, there are few studies on clay extraction pits aiming to evaluate the dynamics of nutrients via litter deposition by tree species used for revegetation. The quantification of deposition rates and the quality assessment of litter are ways of assessment of plant species in which concerns their contribution for the cycling of nutrients in the environment.

Tree species tend to differ regarding the amount of deposited litter, resulting in a lower or higher deposition of nutrients in reforestation (BERTALOT et al., 2004). In addition, litter nutritional quality of each species will reflect to the rates of decomposition and release of nutrients into soils. According to the edaphoclimatic conditions, the rate of litter decomposition varies depending on certain factors, such as lignin, polyphenol, cellulose, 
carbon, nitrogen, phosphorus, sulfur levels and $\mathrm{C}: \mathrm{N}$ ratio (MONTEIRO; GAMA-RODRIGUES, 2004; AITA; GIACOMINE 2003). Species which litter has high levels of lignin, polyphenol and cellulose show low decomposition rate and lower release of nutrients (SWIFT et al., 1979).

Chiaranda et al. (1983), comparing litter deposition in experimental stands of four-year-old Mimosa scabrella and Eucalyptus vimnalis located in the mining region of Paraná, observed a greater litter deposition in the planting of such Fabaceae species in relation to the planting of eucalyptus, 6.30 and $3.00 \mathrm{Mg} \mathrm{ha}^{-1}$ year $^{-1}$, respectively. On the other hand, Balieiro et al. (2004) found no significant differences in the rates of litter deposition between species Pseudosamanea guachapele Kunth (Harms) (Legume) and Eucalyptus grandis (12.7 and 11.8 $\mathrm{Mg} \mathrm{ha}^{-1}$ year $^{-1}$, respectively).

According to some authors, there are various (biotic and abiotic) factors that influence the rates of litter deposition, such as the type of vegetation, plant species, altitude, latitude, rainfall, temperature, lighting schemes, topography, deciduousness, successional stage, water availability and soil characteristics (FREITAS et al., 2013; NASCIMENTO et al., 2013; DICKOW et al., 2012; PINTO et al., 2008; FIGUEIREDO FILHO et al., 2003).

The aim of this study was to evaluate the contribution of pure stands of Eucalyptus camaldulensis and Acacia mangium in litter deposition and nutrients return to in clay extraction pits in northern Rio de Janeiro (RJ).

\section{MATERIAL AND METHODS}

The study was conducted in an extraction pit of clay belonging to Cerâmica Stilbe Ltda, located in the district of Poço Gordo (2150'28.5" S, $\left.41^{\circ} 14^{\prime} 31.4^{\prime \prime} \mathrm{W}\right)$, municipality of Campos dos Goytacazes, RJ. The climate of Rio northern region is classified according to Köppen as type Aw, with a hot and humid tropical climate, dry winter and rainy summer, and annual rainfall of around $1,020 \mathrm{~mm}$. The monthly temperature and rainfall averages of the study area, recorded from May 2006 to June 2007 were $24.1^{\circ} \mathrm{C}$ and $86.6 \mathrm{~mm}$, respectively.

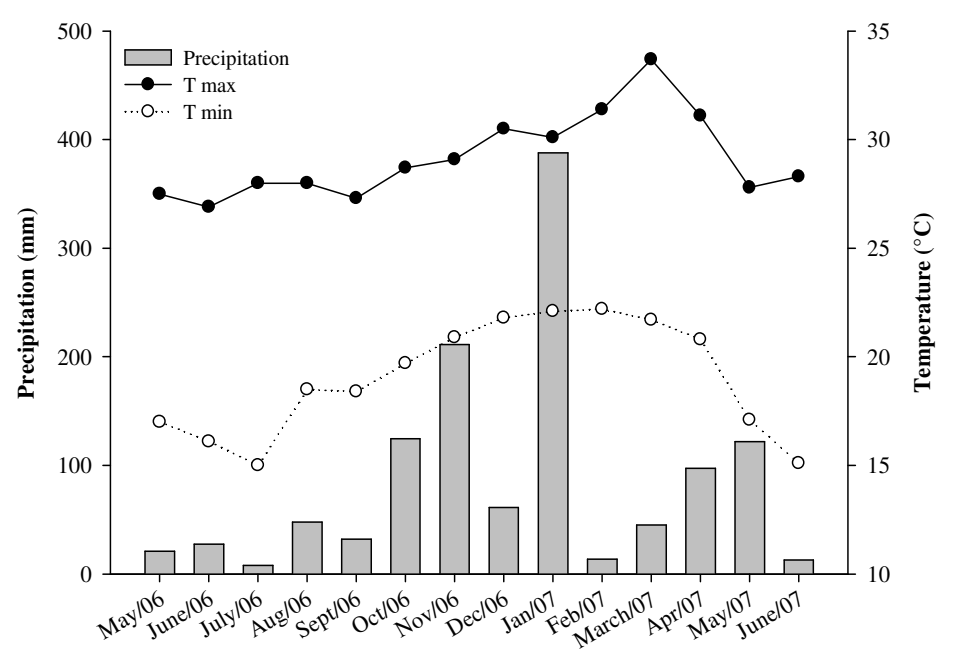

Figure 1. Precipitation and temperature maximum and minimum averages in the study area from May 2006 to June 2007.

The original soil of the pit area under study is classified according to the Brazilian soil classification society (EMBRAPA, 1999) as a typical Sodic Haplic Cambisol, with a depth of excavation of approximately $3 \mathrm{~m}$. I such process, the surface layer with higher organic matter content was removed and returned to the pit surface after the extraction of clay. The extraction pit was mechanically leveled and kept under fallow for two years, period in which brachiaria [Brachiaria mutica
(Forsk.) Stapf.] emerged as spontaneous vegetation (SCHIAVO, 2005).

After the fallow period, there was the preparation of the area with one plowing and two harrowings. The extraction pit was revegetated in August 2002, with pure stands of Acacia mangium and Eucalyptus camaldulensis (SCHIAVO, 2005) by using a two-meter spacing between plants and three-meter spacing between rows $(2 \times 3 \mathrm{~m})$. We fertilized the pits (tree holes) with Araxá rock phosphate $(\mathrm{Ca}=25,9 \% ; \mathrm{P}$ total $=11,6 \%$ e $\mathrm{P}$ 
disponible $=5,9 \%$ ), with an applied dose equivalent to $100 \mathrm{mg}$ per pit. Table 1 shows the chemical characterization, sum of the bases (SB), cation exchange capacity (CEC) (EMBRAPA, 1997), as well as the nitrogen (CHN/S ANALYSER-
PERKYN ELMER modelo PE 2400-II) and total organic carbon (TOC) (YEOMANS AND BREMMER,1988) from 0.00-0.05 m layer of soil from an area of clay extraction, four years after planting.

Table 1. Chemical characterization, nitrogen and total organic carbon (TOC) of the 0.00-0.05 m soil layer from an area of clay extraction revegeted with pure stands of the Eucalyptus camaldulensis and Acacia mangium four years after planting.

\begin{tabular}{|c|c|c|c|c|c|c|}
\hline \multirow{2}{*}{ Sistemas } & $\mathrm{pH}$ & $\mathrm{Ca}$ & $\mathrm{Mg}$ & $\mathrm{Na}$ & $\mathrm{Al}$ & $\mathrm{H}+\mathrm{Al}$ \\
\hline & \multicolumn{6}{|c|}{ 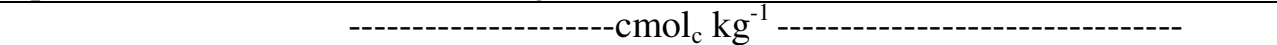 } \\
\hline E. camaldulensis & 5,64 & 6,20 & 4,12 & 1,52 & 0,10 & 2,86 \\
\hline A. mangium & 4,88 & 5,51 & 5,02 & 2,78 & 0,00 & 4,62 \\
\hline \multirow{2}{*}{ Sistemas } & SB & $\mathrm{CEC}_{\mathrm{pH} 7,0}$ & $\mathrm{~K}$ & $\mathrm{P}$ & TOC & $\mathrm{N}$ \\
\hline & \multicolumn{2}{|c|}{$\mathrm{cmol}_{\mathrm{c}} \mathrm{kg}^{-1}$} & \multicolumn{2}{|c|}{$\mathrm{mg} \mathrm{kg}^{-1}$} & \multicolumn{2}{|c|}{$\mathrm{g} \mathrm{kg}^{-1}$} \\
\hline E. camaldulensis & 13,06 & 15,92 & 477,50 & 65,77 & 27,60 & 1,50 \\
\hline A. mangium & 14,08 & 18,39 & 378,33 & 26,63 & 25,67 & 1,90 \\
\hline
\end{tabular}

A randomized block design experiment with two treatments and three replications was performed: pure stands of $E$. camaldulensis and $A$. mangium. Two rows of E. camaldulensis plants forming the border were allocated between the stands. The experimental plot consisted of 16 plants.

At the stage of seedling production, species were inoculated with arbuscular mycorrhizal fungi (Glomus macrocarpum, Glomus etunicatum and Entrophospora colombiana) isolated from an area of clay extraction, belonging to Cerâmica Caco Manga Ltda., located in the district of Ururaí in the municipality of Campos dos Goytacazes-RJ. The isolated fungi, belonging to the inoculum bank of UENF's soil lab, was multiplied in plants of Urochoa bryzantha in a mixture of soil and sand in the ratio $1: 2(\mathrm{v}: \mathrm{v})$. In addition to the AMF, the species $A$. mangium and $S$. virgata were inoculated (in the seed) with a specific strain of rhizobium, with BR 3609, BR 6009 for AM and BR 5401 for SV. These were from Embrapa Agrobiologia, Seropédica-RJ.

To evaluate the deposition and the nutritional quality of the litter, two collectors (circular shape, diameter $0.5 \mathrm{~m}$, made of $1 \mathrm{~mm}$ mesh,) per plot were installed on plots surface. These were arranged between the inter-rows and suspended at approximately $1 \mathrm{~m}$ above the ground. Sampling occurred every 45 days, and the samples were separated into leaves, branches, reproductive structures and waste (bark and structures smaller than $1 \mathrm{~cm}$ ), for a period of 12 months (from July 2006 to June 2007).

After the collection of litter, samples were dried in a kiln at $65^{\circ} \mathrm{C}$ until reaching a constant weight and they were weighed in a digital scale precision $(0.001 \mathrm{~g})$. The obtained values $\left(\mathrm{g} \mathrm{m}^{-2}\right)$ were used to estimate the quarterly and total average of litter production, in $\mathrm{Mg} \mathrm{ha}^{-1}$. After dried and weighed, the separation of the most representative material in the total amount deposited and with greater potential for mineralization was performed: leaves, leaflets and phyllodes of the species were simply treated as leaves. This material was crushed in a mill (Willey type) with a 30 mesh sieve and stored in airtight flasks. The evaluated nutrients were: $\mathrm{N}, \mathrm{P}, \mathrm{K}, \mathrm{Ca}$ and $\mathrm{Mg}$. Total $\mathrm{N}$ was determined by the Nessler method (Jackson et al., 1965), P by colorimetry, $\mathrm{K}$ by flame photometry, $\mathrm{Ca}$ and $\mathrm{Mg}$ by atomic absorption spectrophotometry, after sulfuric digestion. $\mathrm{C}$ concentrations were determined by dry combustion method (CHN/S ANALYSERPERKYN ELMER model PE 2400-II). The polyphenol (Po) level was determined by the method described by Anderson and Ingram (1996). From the data of $\mathrm{C}, \mathrm{N}, \mathrm{P}$ and polyphenol, were calculated C:N (carbon/nitrogen), C:P (carbon/phosphorus) and Po:N (polyphenol/nitrogen) ratio.

The evaluation of the homogeneity of error variances was performed by Cochran's test. Subsequently, the results were submitted to the analysis of variance with the application of Scott Knott test at 5\% probability.

\section{RESULTS AND DISCUSSION}

Litter deposition valures by A. mangium and E. camaldulensis can be seen in Table 1. It was found that only A. mangium showed variation between seasons regarding litter deposition, and they were significantly higher in winter and spring 
(dry season) compared to the other seasons (Table 1).

As for the total litter deposited throughout the year, there is a significant difference between the plantings, in which $A$. mangium stand had the highest deposition rate (Table 2). Most studies related to litter production demonstrate that leguminous species have higher yields than nonleguminous ones (SCHUMACHER et al., 2003). The author justifies that the higher litter production by leguminous species is mainly due to its fast growth and higher efficiency in the use of nutrients extracted from the soil, compared with the other species.

Table 2. Seasonal and total (one year) deposition of litter added to the soil by pure stands of Eucalyptus camaldulensis and Acacia mangium, four years after planting.

\begin{tabular}{|c|c|c|c|c|c|}
\hline \multirow{2}{*}{ Species } & Winter & Spring & Summer & Autumm & Total \\
\hline & \multicolumn{4}{|c|}{$\mathrm{Mg} \mathrm{ha}^{-1}$} & Mg ha $^{-1}$ year $^{-1}$ \\
\hline A. mangium & $2.73 \mathrm{a}$ & $2.58 \mathrm{a}$ & $1.57 \mathrm{~b}$ & $1.52 \mathrm{~b}$ & $8.4 \mathrm{~A}$ \\
\hline E. camaldulensis & $1.69 \mathrm{a}$ & $1.51 \mathrm{a}$ & $1.39 \mathrm{a}$ & $1.75 \mathrm{a}$ & $6.3 \mathrm{~B}$ \\
\hline
\end{tabular}

Means followed by the same lower case letter in the line and capital letter in the column do not differ according to Scott Knott test at 5\%. Winter: litter the months of July, August, September; Spring: October, November and December; Summer: January, February and March; and Autumn: April, May and June.

The value found in this study for annual litter deposition in the stand of E. camaldulensis (Table 2) is higher than the ones found by Zaia and Gama-Rodrigues (2004) in stands of 6-year-old $E$. camaldulensis (4.53 $\mathrm{Mg} \mathrm{ha}^{-1} \mathrm{year}^{-1}$ ) in tableland soil, in Northern Rio de Janeiro. On the other hand, the result observed for litter deposition on stands of $A$. mangium was close to the one found by Andrade et al. (2000) (9.1 Mg ha ${ }^{-1}$ year $^{-1}$ ).

It was observed that the material forming the litter in both stands consisted mainly of leaves, ranging from $49 \%$ (A. mangium) to $58 \%$ (E. camaldulensis) (Table 3), which shows the importance of this fraction to the litter. Studies on tropical forests have also shown large deposition of leaves, constituting around $70 \%$ of the material annually deposited (SWAMY; PROCTOR, 1994; ESPIG et al., 2009). Balieiro et al. (2004) found the percentages of $85 \%$ and $58 \%$, respectively, for pure stands of Pseudosamanea guachapele and Eucalyptus grandis.

Table 3. Amount of total (one year) litter added to the soil by pure stands of Eucalyptus camaldulensis and Acacia mangium, four years after planting.

\begin{tabular}{lcccc}
\hline \multirow{2}{*}{ Species } & Leaves & Branches & Reproductive E & Waste \\
\cline { 2 - 5 } & \multicolumn{4}{c}{$\mathrm{Mg} \mathrm{ha}^{-1} \mathrm{year}^{-1}$} \\
\hline A. mangium & $4.11(49)^{*} \mathrm{a}$ & $1.95(23) \mathrm{a}$ & $1.67(20) \mathrm{a}$ & $0.72(8) \mathrm{a}$ \\
E. camaldulensis & $3.66(58) \mathrm{b}$ & $2.04(32) \mathrm{a}$ & $0.05(1) \mathrm{b}$ & $0.59(9) \mathrm{a}$ \\
\hline
\end{tabular}

Means followed by the same letter in the column do not differ according to the Scott Knott test at 5\%.* Relative contribution (\%) of leaves, branches, reproductive structures (reproductive E) and waste in the composition of total litter.

Significant differences were observed on the levels of $\mathrm{N}$ in the leaf litter between the two species (Table 4). Forrester et al. (2005) observed higher N levels in the litter of $A$. mearnsii in relation to the one of E. globolus. Fortes (2000), evaluating litter deposition by $A$. mangium in areas of alkaline bauxite wastes covered with ashes, observed a $\mathrm{N}$ level around $18.60 \mathrm{~g} \mathrm{~kg}^{-1}$, close to the mean observed for this species in this study. Froufe (1999) found values of around 14.44 and $9.26 \mathrm{~g} \mathrm{~kg}^{-1}$ for $A$. mangium and Eucalyptus grandis, respectively, also confirming the values found for E. camaldulensis and $A$. mangium in this study.

It was observed that the species, in most of the stands, showed reduced levels of $\mathrm{N}$ in the summer and autumn compared with the other seasons (Table 4). This pattern may be related to the high rainfall occurred in the summer (Figure 1), resulting in the upwelling of the groundwater, causing a period of flooding in the area. Such a condition can be promoted lower availability of $\mathrm{N}$ in the soil due to the lower rate of mineralization, since the flooded soil in anaerobic decomposition of organic matter occurs more slowly than in drained soils, because smaller and less efficient group bacteria perform this function under these conditions (SILVA et al., 2011; VAHL, 1999). Flooding may also have caused a reduction in the $\mathrm{N}$ available in the soil through ammonia volatilization, leaching, denitrification and surface runoff (SILVA et al., 2011; SOUSA et al., 2004). According Sousa et al. (2004), the leading cause of $\mathrm{N}$ losses in 
flooded soils is denitrification. Initial losses occur soon after flooding, when nitrate that had been mineralized during aerobic period $\left(\mathrm{NO}_{3}{ }^{-}\right)$is denitrified to $\mathrm{N}_{2} \mathrm{O}$ and $\mathrm{N}_{2}$ gas.

Table 4. Average levels of nutrients in leaf litter of pure stands of Eucalyptus camaldulensis and Acacia mangium, four years after planting.

\begin{tabular}{|c|c|c|c|c|c|}
\hline \multirow{2}{*}{ Species } & Winter & Spring & Summer & Autumm & Average \\
\hline & \multicolumn{5}{|c|}{$\mathrm{N}\left(\mathrm{g} \mathrm{kg}^{-1}\right)$} \\
\hline E. camaldulensis & $13.13 \mathrm{bA}$ & $12.23 \mathrm{bA}$ & $6.97 \mathrm{bB}$ & $8.29 \mathrm{bB}$ & $10.15 \mathrm{~b}$ \\
\hline \multirow[t]{2}{*}{ A. mangium } & $21.03 \mathrm{aA}$ & $20.68 \mathrm{aA}$ & $11.98 \mathrm{aB}$ & $12.42 \mathrm{aB}$ & $16.53 \mathrm{a}$ \\
\hline & \multicolumn{5}{|c|}{$\mathrm{P}\left(\mathrm{g} \mathrm{kg}^{-1}\right)$} \\
\hline E. camaldulensis & $1.34 \mathrm{aA}$ & $1.02 \mathrm{aA}$ & $0.70 \mathrm{aB}$ & $0.76 \mathrm{bB}$ & $0.95 \mathrm{a}$ \\
\hline \multirow[t]{2}{*}{ A. mangium } & $1.12 \mathrm{aA}$ & $1.08 \mathrm{aA}$ & $0.81 \mathrm{aA}$ & $1.26 \mathrm{aA}$ & $1.07 \mathrm{a}$ \\
\hline & \multicolumn{5}{|c|}{$\mathrm{K}\left(\mathrm{g} \mathrm{kg}^{-1}\right)$} \\
\hline E. camaldulensis & $2.76 \mathrm{bC}$ & $1.40 \mathrm{bD}$ & $4.97 \mathrm{aA}$ & $3.92 \mathrm{bB}$ & $3.27 \mathrm{~b}$ \\
\hline \multirow[t]{2}{*}{ A. mangium } & $4.95 \mathrm{aA}$ & $2.20 \mathrm{aB}$ & $3.80 \mathrm{bA}$ & $5.48 \mathrm{aA}$ & $4.11 \mathrm{a}$ \\
\hline & \multicolumn{5}{|c|}{$\mathrm{Ca}\left(\mathrm{g} \mathrm{kg}^{-1}\right)$} \\
\hline E. camaldulensis & $11.72 \mathrm{aB}$ & $15.91 \mathrm{aA}$ & $12.50 \mathrm{aB}$ & $11.07 \mathrm{aB}$ & $12.81 \mathrm{a}$ \\
\hline \multirow[t]{2}{*}{ A. mangium } & $4.88 \mathrm{bA}$ & $10.84 \mathrm{bA}$ & $7.27 \mathrm{bA}$ & $7.31 \mathrm{bA}$ & $7.49 \mathrm{~b}$ \\
\hline & \multicolumn{5}{|c|}{$\operatorname{Mg}\left(\mathrm{g} \mathrm{kg}^{-1}\right)$} \\
\hline E. camaldulensis & $2.69 \mathrm{aA}$ & $2.40 \mathrm{aA}$ & $2.84 \mathrm{aA}$ & $2.23 \mathrm{aA}$ & $2.54 \mathrm{a}$ \\
\hline A. mangium & $3.42 \mathrm{aA}$ & $2.86 \mathrm{aA}$ & $2.31 \mathrm{aA}$ & $1.69 \mathrm{aA}$ & $2.57 \mathrm{a}$ \\
\hline
\end{tabular}

* Lowercase letters compare species, within each season, capital letters compare seasons, within each species, according to Scott Knott test at 5\%. Winter: litter the months of July, August, September; Spring: October, November and December; Summer: January, February and March; and Autumn: April, May and June.

In addition to these factors, there is also the negative influence of flooding in biological nitrogen fixation (BNF) by leguminous species, due to the fact that the nodule of most of the known species is unable to tolerate excess moisture for a long time, since they require $\mathrm{O}_{2}$ for energy generating processes (FRANCO; NEVES, 1992).

Furthermore, the reduction of nutrients in the plant caused by the flooding of the roots can be attributed to factors such as the accumulation of toxic substances in these parts, which inhibit the absorption of mineral nutrients and cause the decrease in the availability of these elements in the soil (DREW, 1997; CARVALHO; ISHIDA, 2002).

The levels of $\mathrm{C}$ and polyphenols (Po) in the leaves of $A$. mangium and $E$. camaldulensis showed no significant difference (Table 5). The amounts of polyphenols of the E. camaldulensis leaf litter (Table 5) were lower than those observed by Costa et al. (2005), in stands of E. grandis with different ages, which ranged from 57 to $61 \mathrm{~g} \mathrm{~kg}^{-1}$.

According to Constantinides and Fownes (1994) litter polyphenols are usually negatively correlated with the rate of decomposition, and this is mainly due to the capacity of this group of substances to complex with forms of N. Studies by Resende et al. (2013) suggest that the level of polyphenol contained in plant residues is crucial for the growth of the decomposer agents population of the soil fauna and, hence, for the rate of decomposition of the material.

Table 5. Average levels of carbon (C), polyphenols (Po) and C:N, C:P and Po:N ratios in g per kg of dry litter matter of pure stands of Eucalyptus camaldulensis and Acacia mangium, four years after planting (average of four seasons and three replications). $\mathrm{P}=$ phosphorus.

\begin{tabular}{lccccc}
\hline \multirow{2}{*}{ Species } & $\mathrm{C}$ & Polyphenols & $\mathrm{C}: \mathrm{N}$ & $\mathrm{C}: \mathrm{P}$ & Po:N \\
\cline { 2 - 6 } & & \multicolumn{5}{c}{$\mathrm{g} \mathrm{kg}^{-1}$ soil } \\
\hline E. camaldulensis & $508 \mathrm{a}$ & $48.33 \mathrm{a}$ & $55.30 \mathrm{a}$ & $535 \mathrm{a}$ & $4.78 \mathrm{a}$ \\
A. mangium & $493 \mathrm{a}$ & $41.41 \mathrm{a}$ & $32.44 \mathrm{~b}$ & $464 \mathrm{a}$ & $2.84 \mathrm{~b}$ \\
\hline
\end{tabular}

* Means followed by the same letter in the column do not differ from each other, according to the Scott Knott test at 5\%. N= nitrogen 
The Po: $\mathrm{N}$ ratio was lower in A. mangium than in E. camaldulensis (Table 5). Low levels of polyphenols and high levels of $\mathrm{N}$ in the organic residues contribute to the elevated rates of decomposition, which can generate more pronounced rates of $\mathrm{N}$ mineralization, increasing the availability of ammonium in the environment. Considering that in such situations the competition of heterotrophic microorganisms for ammonium will be less intense and the activity of nitrifying microorganisms will be higher (VITOUSEK et al., 1982; RACHID et al., 2013) an increase in the nitrate availability may also occur in the soil (RACHID et al., 2013; VOIGTLAENDER et al., 2012).

The C:N ratio showed a similar pattern to the Po:N ratio, in which regarding the A. mangium, lower values were observed on average compared with E. camaldulensis, indicating a better quality (material most easily decomposable by edaphic biota with consequent availability of nutrients in the soil) of the material forming the litter of the legume. According to Gama-Rodrigues et al. (1999), the decomposition rate of litter is regulated by the nutritional quality of the substrate. These authors point out that, reductions in the values of $\mathrm{C}: \mathrm{N}$ ratio, and increases in the concentrations of $\mathrm{N}, \mathrm{P}, \mathrm{K}$ and
$\mathrm{Mg}$, promote faster litter decomposition due to the fact that its high nutritional quality meets the need of the decomposer organisms, especially microorganisms.

Both evaluated species presented equivalent deposition of $\mathrm{K}, \mathrm{Ca}$ and $\mathrm{Mg}$ in the evaluated year, with statistically similar values. On the other hand, as for the deposition of $\mathrm{N}$ and $\mathrm{P}$, there was a major contribution in the planting of A. mangium in relation to E. camaldulensis. Higher deposition of $\mathrm{N}$ and $\mathrm{P}$ may reflect higher levels of these nutrients in the soil, after the litter decomposition process. Rachid et al. (2013) observed increased levels of $\mathrm{N}$ in soils under stands of A. mangium compared to stands of Eucalyptus spp.

The amount of $\mathrm{N}$ deposited by pure stands of E. camaldulensis (Table 6) was higher than the values observed by Zaia and Gama-Rodrigues (2004) for stands of the same species $\left(26 \mathrm{~kg} \mathrm{ha}^{-}\right.$ ${ }^{1}$ year $\left.^{-1}\right)$. Moreover, it has been reported by Brinkley et al. (1992) for E. saligna (30-40 $\left.\mathrm{kg} \mathrm{ha}^{-1} \mathrm{year}^{-1}\right)$. On the other hand, the value observed for A. mangium was lower than the ones found by Voigtlaender et al. (2012) (97 kg ha-1 year $\left.^{-1}\right)$ and Bouillet et al. (2008) (123.60 kg ha ${ }^{-1}$ year $\left.^{-1}\right)$, in São Paulo, and Andrade et al. (2000) (109 kg ha ${ }^{-1}$ year $\left.^{-1}\right)$ in Rio de Janeiro, for stands of the same species.

Table 6. Annual nutrient deposition $\left(\mathrm{kg} \mathrm{ha}^{-1} \mathrm{year}^{-1}\right)$ through leaf litter of pure stands of Eucalyptus camaldulensis and Acacia mangium, four years after planting.

\begin{tabular}{|c|c|c|c|c|c|}
\hline \multirow{2}{*}{ Nutrientes } & $\mathrm{N}$ & $\mathrm{P}$ & $\mathrm{K}$ & $\mathrm{Ca}$ & $\mathrm{Mg}$ \\
\hline & \multicolumn{5}{|c|}{$\mathrm{kg} \mathrm{ha}^{-1}$ year $^{-1}$} \\
\hline E. camaldulensis & $35.46 \mathrm{~b}$ & $3.31 \mathrm{~b}$ & $18.85 \mathrm{a}$ & $44.97 \mathrm{a}$ & $10.33 \mathrm{a}$ \\
\hline A. mangium & $68.50 \mathrm{a}$ & $4.47 \mathrm{a}$ & $18.32 \mathrm{a}$ & $30.79 \mathrm{a}$ & $8.78 \mathrm{a}$ \\
\hline
\end{tabular}

*Means followed by the same letter in the column do not differ from each other according to the Scott Knott test at 5\%.

It was found that the amounts of macronutrients in the litter allowed the establishment of two different sequences: $\mathrm{Ca}>\mathrm{N}>\mathrm{Mg}>\mathrm{K}>\mathrm{P}$ for E. camaldulensis and $\mathrm{N}>\mathrm{Ca}>\mathrm{Mg}>\mathrm{K}>\mathrm{P}$ for $A$. mangium. In the sequences only $\mathrm{N}$ shifts place with $\mathrm{Ca}$, the other nutrients present the same sequence for both species. In Eucalyptus saligna and Mimosa scabrella (bracatinga) stands, Souza and Davide (2001) found similar sequences to those observed in this study.

\section{CONCLUSION}

The planting of Acacia mangium in clay extraction pit contributed to a larger (around 30\%) annual deposition of total litter and to a better litter quality compared to Eucalyptus camaldulensis, with higher levels and amounts of $\mathrm{P}$ and $\mathrm{N}$ in the leaf and lowest $\mathrm{C}: \mathrm{N}$ and $\mathrm{Po}: \mathrm{N}$ ratios.

RESUMO: O objetivo deste estudo foi avaliar a contribuição de plantios puros de Eucalyptus camaldulensis (Eucalipto) e Acacia mangium (Acácia) na deposição de serapilheira e retorno de nutrientes em uma cava de extração de argila na região norte fluminense (RJ). Realizou-se um experimento, cujo delineamento utilizado foi o de blocos casualizados com dois tratamentos e três repetições. Para a avaliação do aporte anual de serapilheira e nutrientes (N, P, K, $\mathrm{Ca}$ e Mg), utilizaram-se coletores circulares, durante o período de um ano (julho de 2006 a junho de 2007). O plantio de Acacia mangium na cava de extração de argila contribuiu com o maior aporte anual de serapilheira total, bem como, uma serapilheira de melhor qualidade em relação ao Eucalyptus camaldulensis, apresentando maiores teores de $\mathrm{P}$ e $\mathrm{N}$ e 
menores relações C:N e Polifenol:N. Este fato possivelmente permite maiores taxas de decomposição pelos microrganismos edáficos, e consequente mais rápida liberação desses nutrientes para o solo. Além disso, o plantio da leguminosa apresentou maior aporte anual de $\mathrm{P}$ e $\mathrm{N}$.

PALAVRAS-CHAVE: Ciclagem de nutrientes. Área degradada. Leguminosa arbórea.

\section{REFERENCES}

AITA, C.; GIACOMINI, S. J. Decomposição e liberação de nitrogênio de resíduos culturais de plantas de cobertura de solo solteiras e consorciadas. Revista Brasileira de Ciência do Solo, Viçosa, v. 27, n. 2, p. 601612, jul./aug. 2003.

ALBUQUERQUE, M. P.; MACHADO, A. M. B.; MACHADO, A. F.; VICTORIA, F. C. \& MORSELLI, T. B. G. A. Fauna edáfica em sistema de plantio homogêneo, sistema agroflorestal e em mata nativa em dois municípios do Rio Grande do Sul, Brasil. Biociências, Porto Alegre, v. 17, n. 1, p. 59-66, dec. 2009.

ANDERSON, J. D.; INGRAM, J. S. I. Tropical soil biology and fertility: A handbook of methods. 2. ed. Wallingford: CAB International, 1996, $171 \mathrm{p}$.

ANDRADE, A. G.; COSTA, G. S.; FARIA, S. M. Deposição e decomposição da serrapilheira em povoamentos de Mimosa caesalpiniifolia, Acacia mangium e Acacia holosericia com quatro anos de idade em planossolo. Revista Brasileira de Ciência do Solo, Viçosa, v. 24, n. 4, p. 777-785, 2000.

BALIEIRO, Fabiano de Carvalho. Dinâmica de nutrientes e da água em plantios puros e consorciado de Pseudosamanea guachapele (Kunth) Harms e Eucalyptus grandis W. Hill ex Maiden. 2002. 82p. Tese (Doutorado em Agronomia Ciência do Solo) - Curso de Pós-Graduação em Agronomia Ciência do Solo, Universidade Federal Rural do Rio de Janeiro, Seropédica, 2002.

BALIEIRO, F. C.; DIAS, L. E.; FRANCO, A. A.; CAMPELLO, E. F. C.; FARIA, S. M. Acúmulo de nutrientes na parte aérea, na serapilheira acumulada sobre o solo e decomposição de filódios de Acacia mangium Will.

Ciência Florestal, Santa Maria, v. 14, n. 1, p. 59-65, 2004.

BATISTA, Q. R.; FREITAS, M. S. M.; MARTINS, M. A.; SILVA, C. F. Bioqualidade de área degradada pela extração de argila, revegetada com Eucalyptus spp. e sabiá. Caatinga, Mossoró, v. 21, n. 1, p. 169-178, 2008.

BERTALOT, M. J. A.; GUERRINI, I. A.; MENDOZA, E.; DUBOC, E.; BARREIROS, R. M.; CORRÊA, F. M. Retorno de nutrientes ao solo via deposição de serapilheira de quatro espécies leguminosas arbóreas na região de Botucatu -São Paulo, Brasil. Scientia Forestalis, Piracicaba, n. 65, p. 219-277, jun. 2004.

BOUILLET, J. P.; LACLAU, J. P.; GONÇALVES, J. L. M.; MOREIRA, M. Z.; TRIVELIN, P. C. O.; JOURDAN, C.; SILVA, E. V.; PICCOLO, M. C.; TSAI, S. M.; GALIANA, A. Mixed-species plantations of Acacia mangium and Eucalyptus grandis in Brazil. 2: Nitrogen accumulation in the stands and biological $\mathrm{N}_{2}$ fixation. Forest Ecology and Management, Amsterdam, v. 225, n. 12; p. 3918-3930, jun. 2008. http://dx.doi.org/10.1016/j.foreco.2007.10.050

CABRAL, L. N.; ALBUQUERQUE, H. N. Impactos sócioambientais com a extração de minérios em uma área rural de Campina Grande-PB. Revista de Biologia e Farmácia (BIOFAR), Paraíba, v. 8, n. 2, p. 76-85, 2012.

CARVALHO, C. J. R.; ISHIDA, F. Y. Respostas de pupunheiras (Bactris gasipaes Kunth) jovens ao alagamento. Pesquisa Agropecuária Brasileira, Brasília, v. 37, n. 9, p. 1231-1297, set. 2002.

http://dx.doi.org/10.1590/S0100-204X2002000900005 
CHIARANDA, J. R.; POGGIANI, F.; SIMÕES, J. W. Crescimento das árvores e deposição de folhedo em talhões florestais plantados em solos alterados pela mineração do xisto. Instituto de Pesquisas e Estudos Florestais (IPEF), Piracicaba, v. 25, p. 25-28, 1983.

CONSTANTINIDES, M.; FOWNES, J. H. Nitrogen mineralization from leaves and litter of tropical plants: relationship to nitrogen, liginin and soluble polyphenol concentrations. Soil Biology and Biochemestry, Elmsford, v. 29, p. 49-55, jan. 1994. http://dx.doi.org/10.1016/0038-0717(94)90194-5

CORRÊA NETO, T. A. C; PEREIRA, M. G.; CORREA, M. E. F.; ANJOS, L. H. C. Deposição de serapilheira e mesofauna edáfica em áreas de eucalipto e floresta secundária. Floresta e Ambiente, Rio de Janeiro, v. 8, n. 1, p. 70-75, jan./dec. 2001.

COSTA, G. S.; GAMA-RODRIGUES, A. C. \& CUNHA, G. M. Decomposição e liberação de nutrientes da serapilheira foliar em povoamentos de Eucalyptus grandis no norte fluminense. Revista Árvore, Viçosa, v. 29, p. 563-570, 2005.

COSTA JUNIOR, Persival Ferreira. Comportamento de leguminosas arbóreas inoculadas com fungos micorrízicos arbusculares e rizóbio em estéril de extração de argila. 1997.71f. Dissertação (Mestrado em Produção Vegetal) - Curso de Pós-Graduação em Produção Vegetal, Universidade Estadual do Norte Fluminense Darcy Ribeiro, Campos dos Goytacazes, 1997.

DICKOW, K. M. C.; MARQUES, R.; PINTO, C. B.; HÖFER, H. Produção de serapilheira em diferentes fases sucessionais de uma floresta subtropical secundária, em Antonina, PR. Cerne, Lavras, v. 18, n. 1, p. 75-86, jan./mar. 2012.

DREW, M. C. Oxygen deficiency and root metabolism: injury and acclimation under hypoxia and anoxia. Annual Review of Plant Physiology and Plant Molecular Biology, USA, v. 48, p. 223-250, 1997. http://dx.doi.org/10.1146/annurev.arplant.48.1.223

EMBRAPA. Manual de métodos de análise de solo. 2. ed. Rio de Janeiro: Centro Nacional de Pesquisas de Solos - Embrapa Solos, 1997, 210p.

EMBRAPA. Sistema brasileiro de classificação de solos. ed. Rio de Janeiro: Centro Nacional de Pesquisas de Solos - Embrapa Solos, 1999, 412p.

ESPIG, S. A.; FREIRE, F. J.; MARANGON, L. C.; FERREIRA, R. L. C.; FREIRE, M. B. G. S.; ESPIG, D. B. Sazonalidade, composição e aporte de nutrientes da serapilheira em fragmento de Mata Atlântica. Revista Árvore, Viçosa, v. 33, n. 5, p. 949-956, 2009.

FERREIRA, R. L. C.; LIRA JUNIOR, M. A.; ROCHA, M. S.; SANTOS, M. V. F.; LIRA, M. A.; BARRETO, L. P. Deposição e acúmulo de matéria seca e nutrientes em serapilheira em um bosque de sabiá (Mimosa caesalpinifolia Benth.). Revista Árvore, Viçosa, v. 31, n. 1, p. 7-12, 2007.

FIGUEIREDO FILHO, A.; MORAES, G. F.; SCHAAF, L. B.; FIGUEIREDO, D. J. Avaliação estacional da deposição de serapilheira em uma floresta ombrófila mista localizada no sul do Estado do Paraná. Ciência Florestal, Santa Maria, v. 13, p. 11-18, 2003.

FORRESTER, D. I.; BAUHUS, J.; COWIE, A. L. On the success and failure of mixed species tree plantations: lessons learned from a model system of Eucalyptus globulus and Acacia mearnsii. Forest Ecology and Management, Amsterdam, v. 209, n. 1-2, p. 147-155, Apr. 2005.

http://dx.doi.org/10.1016/j.foreco.2005.01.012

FORTES, Jorge Luiz de Oliveira Fortes. Reabilitação de depósitos de rejeito do refino de bauxita com o uso de resíduos industriais e leguminosas arbóreas. 2000. 185f. Tese (Doutorado em Agronomia-Ciência do 
Solo) - Curso de Pós-Graduação em Agronomia-Ciência do Solo, Universidade Federal Rural do Rio de Janeiro, Seropédica, 2000.

FRANCO, A. A.; NEVES, M. C. Fatores limitantes a fixação biológica de nitrogênio. In: CARDOSO, E. J. B. N. CARDOSO, S. M. TSAI E NEVES, M. C. P. (eds.). Microbiologia do solo. Campinas: Sociedade Brasileira de Ciência do Solo, 1992, p. 257-282.

FREITAS, E. C. S.; OLIVEIRA NETO, S. N; FONSECA, D. M.; SANTOS, M. V; LEITE, H. G.; MACHADO, V.D. Deposição de serapilheira e de nutrientes no solo em Sistema Agrossilvipastoril com eucalipto e acácia. Revista Árvore, Viçosa, v. 37, n. 3, May/Jun. 2013.

FROUFE, Luiz Cláudio Maranhão. Decomposição de serapilheira e aporte de nutrientes em plantios puros e consorciados de Eucalyptus grandis Maiden, Pseudosamanea guachapele Dugand e Acacia mangium Willd. 1999. 73f. Dissertação (Mestrado em Agronomia Ciência do Solo) - Curso de Pós-Graduação em Agronomia Ciência do Solo, Universidade Federal Rural do Rio de Janeiro, Seropédica, 1999.

GAMA-RODRIGUES, A. C.; BARROS, N. F.; MENDONÇA, E. S. Alterações edáficas sob plantios puros e misto de espécies florestais nativas do Sudeste da Bahia, Brasil. Revista Brasileira de Ciência do Solo, Viçosa, v. 23, n. 3, p. 581-592, 1999.

JACKSON, M. L. Soil chemical analysis. Ed. New Jersey: Prentice Hall, 1965, 498p.

MECHI, A. E.; SANCHES, D. L. Impactos ambientais da mineração no estado de são Paulo. Estudos avançados, São Paulo, v. 24, n. 68, p. 209-220, 2010.

MENDONÇA, Andréa Vita Reis Mendonça. Reabilitação de cavas de extração de argila e tolerância de espécies florestais a salinidade. 2006. 120f. Tese (Doutorado em Produção Vegetal) - Curso de PósGraduação em Produção Vegetal, Universidade Estadual do Norte Fluminense Darcy Ribeiro, Campos dos Goytacazes, 2006.

MONTEIRO, M. T.; GAMA-RODRIGUES, E. F. Carbon, nitrogen, and microbial biomass activity in different litter structures of a natural forest. Revista Brasileira de Ciência do Solo, Viçosa, v. 28, n. 5, p. 819-826, Sept/Oct. 2004.

NASCIMENTO, A. F. J.; SILVA, T. O.; SAMPAIO, E. V. S. B; ARAÚJO FILHO, R. N.; DANTAS, T. V. P. Quantificação de serapilheira em diferentes áreas sob fragmentos do Parque Nacional Serra de Itabaiana, Sergipe. Semina: Ciências Agrárias, Londrina, v. 34, n. 6, p. 3271-3284, 2013. http://dx.doi.org/10.5433/1679-0359.2013v34n6Sup11p3271

OCHIAI, H.; NAKAMURA, S. A. Função da camada da serapilheira no controle da erosão do solo. In: VILLAS BÔAS, O.; DURIGAN, G. (Org.). Pesquisas em conservação e recuperação ambiental no oeste paulista: resultados da cooperação Brasil/Japão. São Paulo: Instituto Florestal, 2004. p. 168-177.

PINTO, S. I. C.; MARTINS, S. V., BARROS, N. F., DIAS, H. C. T. produção de serapilheira em dois estádios sucessionais de floresta estacional semidecidual na reserva mata do paraíso, em Viçosa, MG. Revista Árvore, Viçosa, v. 32, n. 3, p. 545-556, 2008.

RACHID, C. T. C. C.; BALIEIRO, F. C.; PEIXOTO, R. S.; PINHEIRO, Y. A. S.; PICCOLO, M. C.; CHAER, G. M.; ROSADO, A. S. Mixed plantations can promote microbial integration and soil nitrate increases with changes in the N cycling genes. Soil Biology and Biochemistry, Elmsford, v. 66, p.146-153, 2013. http://dx.doi.org/10.1016/j.soilbio.2013.07.005

RESENDE, A. S., CAMPELlO, E. F. C., SILVA, G. T. A., RODRIGUES, K. M., OLIVEIRA, W. R. D.; CORREIA, M. E. F. Artrópodes do solo durante o processo de decomposição da matéria orgânica. Agronomía Colombiana, Colombia, v. 31, n. 1, p. 89-94, 2013. 
RODRIGUES, L. A.; BARROSO, D. G; MARTINS, M. A.; MENDONÇA, A. V. R. Revegetação de áreas degradadas pela extração de argila no Norte do Estado do Rio de Janeiro. Perspectivas, Campos dos Goytacazes, v. 5, n. 10, p. 88-105, jul./dec. 2006.

SCHIAVO, Jolimar Antônio. Revegetação de áreas degradadas pela extração de argila, com espécies micorrizadas de Acacia mangium, Sesbania virgata e Eucalyptus camaldulensis. 2005. 117f. Tese (Doutorado em Produção Vegetal) - Curso de Pós-Graduação em Produção Vegetal, Universidade Estadual do Norte Fluminense Darcy Ribeiro, Campos dos Goytacazes, 2005.

SCHIAVO, J. A.; MARTINS, M. A.; RODRIGUES, L. A. Avaliação nutricional de mudas de Acacia mangium, Sesbania virgata e Eucalyptus camaldulensis inoculadas com fungos micorrízicos, em casa-devegetação e em cava de extração de argila. Acta Scientiarum. Agronomy, Maringá, v. 31, n. 4, p. 701-707, 2009.

SCHUMACHER, M. V.; BRUN, E. J.; RODRIGUES, L. M.; SANTOS, E. M. Retorno de nutrientes via deposição de serapilheira em um povoamento de acácia-negra (Acacia mearnsii De Wild.) no Estado do Rio Grande do Sul. Revista Árvore, Viçosa, v. 27, n. 6, p. 791-798, nov./dec. 2003.

SELLE, G. L. Ciclagem de nutrientes em ecossistemas florestais. Bioscience Journal, Uberlândia, v. 23, n. 4, p. 29-39, 2007.

SILVA, C. F.; MARTINS, M. A.; SILVA, E. M. R.; PEREIRA, M. G.; CORREIA, M. G. Influência do sistema de plantio sobre características dendrométricas e fauna edáfica em área degradada pela extração de argila.

Revista Brasileira de Ciência do Solo, Viçosa, v. 37, n. 6, p. 1742-1751, nov./dec. 2013.

SILVA, C. F.; SIMÕES-ARAÚJO, J. L.; SILVA, E. M. R.; PEREIRA, M. G.; FREITAS, M. S. M.; SAGGINJÚNIOR, O. J.; MARTINS, M. A. Fungos micorrízicos arbusculares e proteína do solo relacionada à glomalina em área degradada por extração de argila e revegetada com eucalipto e acácia. Ciência Florestal, Santa Maria, v. 22, n. 4, p. 749-761, oct./dec. 2012.

SILVA, L. S.; POCOJESKI, E.; RHODEN, A. C. Dinâmica de nitrogênio mineral após alagamento em solos de várzea do Rio Grande do Sul. Semina: Ciências Agrárias, Londrina, v. 32, n. 2, p. 583-590, abr/jun. 2011. http://dx.doi.org/10.5433/1679-0359.2011v32n2p583

SILVA, R. E. C.; MARGUERON, C. Estudo Geológico-Técnico de Uma Pedreira de Rocha Ornamental no Município de Santo Antônio de Pádua - RJ. Anuário do Instituto de Geociências, Rio de Janeiro, v. 25, p. 125-150, 2002.

SOUSA, R. O.; CAMARGO, F. A. O.; VAHI, L. C. Solos alagados. In: MEURER, E. J. Fundamentos da química do solo. ( $2^{\mathrm{a}}$ Ed). Porto Alegre: Genesis, 2004, 290p.

SOUZA, J. A.; DAVIDE, A. C. Deposição de serapilheira e nutrientes em uma mata não minerada e em plantações de bracatinga (Mimosa scabrella) e de eucalipto (Eucalyptus saligna) em áreas de mineração de bauxita. Cerne, Lavras, v. 7, p. 101-113, 2001.

SWAMY, H. R.; PROCTOR, J. Litterfall and nutrient cycling in four rain forests in the Sringeri area of the Indian Western Ghats. Global Ecology and Biogeography Letters, v. 4, p. 155-165, 1994.

http://dx.doi.org/10.2307/2997533

SWIFT, M. J.; HEAL, O. W.; ANDERSON, J. M. Decomposition in terrestrial ecosystems. $2^{\text {nd }}$ ed. Berkeley: University of California Press, 1979. 372p.

VAHL, L. C. Fertilidade de solos de várzea. In: GOMES, A.S.; PAULETTO, E.A. (2 ${ }^{\mathrm{a}}$ Ed.) Manejo do solo e da água em áreas de várzea. Pelotas: Embrapa Clima Temperado, 1999. p. 119-162. 
VALICHESKI, R. R.; MARCIANO, C. R. Atributos químicos e granulometria do substrato remanescente nas áreas de extração de argila em Campos dos Goytacazes - RJ. Revista Ceres, Viçosa, v. 55, n. 6, p.610-618, 2008.

VITOUSEK, P. M. Nutrient cycling and nutrient use efficiency. American Naturalist, Chicago, v. 119, p. 553572, 1982. http://dx.doi.org/10.1086/283931

VOIGTLAENDER, M; LACLAU, J. P.; GONÇALVES, J. L. M.; PICCOLO, M. C.; MOREIRA, M. Z.;

NOUVELLON, Y.; RANGER, J.; BOUILLET, J. P. Introducing Acacia mangium trees in Eucalyptus grandis plantations: consequences for soil organic matter stocks and nitrogen mineralization. Plant and Soil, The Hague, v. 352, p. 99-11, 2012. http://dx.doi.org/10.1007/s11104-011-0982-9

YEOMANS, J. C.; BREMMER, J. M. A rapid and precise method for routine determination of organic carbon in soil. Communication in Soil Science Plant Analysis, Amsterdam, v. 19, p. 1467-1476, 1988.

http://dx.doi.org/10.1080/00103628809368027

ZAIA, F. C.; GAMA-RODRIGUES, A. C. Ciclagem e balanço de nutrientes em povoamentos de eucalipto na região Norte Fluminense. Revista Brasileira de Ciência do Solo, Viçosa, v. 28, n. 5, p. 843-852, set./out. 2004. 